\title{
Mobile Learning for ICT Training: Enhancing ICT Skill of Teachers in Indonesia
}

\author{
Iin Karmila Yusri and Robert Goodwin
}

\begin{abstract}
Teachers play a significant role in the successful integration of ICT in education. Providing teachers with adequate ICT skills will improve teachers' confidence in using ICT in the school curriculum. In Indonesia, teachers' participation in training is limited due to training location, time, cost, and opportunity. This paper proposes an ICT training program for teachers using mobile phones as a solution for these problems. The proposed program is suitable to different platforms and providing structured training, comprehensive content of ICT training and certification of completion.
\end{abstract}

Index Terms-Teachers, ICT training, mobile learning, mobile phones.

\section{INTRODUCTION}

Teachers play a very important role in any initiative aimed at the integration of information and communication technology (ICT) in education because they are the key component for learning using ICT in schools. Even though there are a number of barriers to integrating ICT into classes, teacher related factors such as competence and attitude, are more significant barriers to the successful integration of ICT in teaching and learning activities than factors associated with technology such as hardware and infrastructure issues [1].

When teachers are hesitant to integrate ICT in all phases of the curriculum, the use of ICTs at school will be not successful. Teachers' hesitation in using ICT in the classroom is mostly because they are not confident of their ICT knowledge and skills. Consequently, preparing teachers with applicable ICT knowledge and skills is significant for successful ICT integration into education. The Asian policy forum on ICT integration into education suggests that the highest priority in ICT integration should be educating teachers, not providing the technology and infrastructure [2].

\section{CURRENT ICT TRAINING AND ICT LEVEL OF TEACHERS IN INDONESIA}

\section{A. Typical ICT Training for Teachers}

The Government of Indonesia through the Ministry of

Manuscript received February 14, 2013; revised April 20, 2013. This work was supported in part by the Directorate of Higher Education Ministry of Education and Culture Indonesia.

I. K. Yusri is with School of Computer Science, Engineering and Mathematics, Flinders University, Adelaide, SA, Australia, on leave from Politeknik Negeri Ujung Pandang, Makassar, Indonesia (email: iin.yusri@flinders.edu.au).

R. Goodwin is with School of Computer Science, Engineering and Mathematics, Flinders University, Adelaide, SA, Australia (email: robert.goodwin@flinders.edu.au)
Education and Culture (MoEC) is continually implementing various efforts to enhance the professionalism of teachers including providing ICT training for teachers. Higher education institutions and communities concerned with ICT development also provide ICT trainings courses for teachers. However, most training presents challenges for teachers to participate. The types of ICT training for teachers in Indonesia and the associated problems are listed in Table I.

TABLE I: THE TYPES OF ICT TRAINING FOR TEACHERS IN INDONESIA AND THE PROBLEMS

\begin{tabular}{|c|c|c|}
\hline $\begin{array}{l}\text { Type of } \\
\text { training }\end{array}$ & Description & $\begin{array}{c}\text { Problems for } \\
\text { teachers and/or schools }\end{array}$ \\
\hline $\begin{array}{l}\text { Face-to- } \\
\text { face }\end{array}$ & $\begin{array}{l}\text { a. Conducted in the capital } \\
\text { city of country/province } \\
\text { or in major cities } \\
\text { b. Only one or a few } \\
\text { representatives per } \\
\text { invited school } \\
\text { c. Training date is depend } \\
\text { on training provider. }\end{array}$ & $\begin{array}{l}\text { a. Geographical challenges } \\
\text { b. Cost for travelling and } \\
\text { accommodation } \\
\text { c. Limited opportunities for } \\
\text { training } \\
\text { d. Teachers have to take } \\
\text { leave to attend the } \\
\text { training }\end{array}$ \\
\hline $\begin{array}{l}\text { In-house } \\
\text { training }\end{array}$ & $\begin{array}{l}\text { a. Conducted in teachers' } \\
\text { school } \\
\text { b. More teachers can } \\
\text { participate } \\
\text { c. Training date is } \\
\text { negotiable between the } \\
\text { training provider and } \\
\text { school }\end{array}$ & $\begin{array}{l}\text { a. Cost for arranging the } \\
\text { training } \\
\text { b. Depends on the } \\
\text { equipment available } \\
\text { c. Teachers absent from } \\
\text { work at the same time } \\
\text { d. Difficult to suit the } \\
\text { teachers and instructor } \\
\text { time }\end{array}$ \\
\hline $\begin{array}{l}\text { Web- } \\
\text { based }\end{array}$ & $\begin{array}{l}\text { a. Conducted virtually at } \\
\text { anytime } \\
\text { b. No limit to number of } \\
\text { participants }\end{array}$ & $\begin{array}{l}\text { a. Require computer and } \\
\text { internet connection } \\
\text { b. Only teachers who have } \\
\text { computer and internet } \\
\text { connection able to } \\
\text { participate }\end{array}$ \\
\hline Blended & $\begin{array}{l}\text { Mix face-to-face and } \\
\text { Web-based training }\end{array}$ & $\begin{array}{l}\text { All problems mentioned } \\
\text { above }\end{array}$ \\
\hline
\end{tabular}

\section{B. ICT Skill of Teachers in Indonesia}

Despite various ICT training programs being conducted for teachers' professional development the ICT skill level of teachers in Indonesia is still quite low as shown by the National Examination of Teachers' Competency which was conducted online in 2011 and 2012. Based on data from [3], the national average score for this examination in 2012 was only $47.84 / 100$ whereas the passing grade is $70 / 100$.

Teachers who could not reach the passing grade were not teachers with a lack of knowledge or experience in teaching. They failed simply because of their low basic ICT skill level. They did not know how to use a mouse and keyboard, how to open the examination application, and how to answer the online examination [4].

With the current level of ICT skill of teachers in Indonesia, it can be concluded that ICT integration into the curriculum in Indonesia is still far from successful. Consequently there is a need for an effective ICT training program for teachers in Indonesia. 


\section{MOBILE LEARNING FOR SKILL TRAINING AND TEACHER TRAINING}

\section{A. Mobile Learning for Skill Training}

Training is a planned and systematic effort to modify or develop knowledge and skill through learning experience and to achieve effective performance in an activity or range of activities [7]. Many people face problems related to geographical location and time-flexibility that restrict their attendance at training sessions. Mobile learning is defined as a form of learning that offers learners opportunity using mobile devices to access learning resources anytime and anywhere [5]. Therefore mobile learning can be a solution for the delivering training problems.

The potential of a mobile learning system in a training environment was studied by [8], [9]. The research suggested that mobile learning is suited to deliver training and provides the benefit of personalized education anytime and anywhere. Another study on mobile learning for training used a Mobile Performance-centered Self-directed System for education and training (mPSS) in engineering education [10]. This project was implemented in real training settings and users expressed satisfaction with the system.

Mobile learning has proven to be an effective tool for skill training. The Mobile Learning Network (MoLeNET), the largest mobile learning initiatives in Europe, has conducted projects specifically aimed at using mobile technologies for vocational learning in areas such as hair beauty, heating and ventilation, plumbing, and wood machining [11]. The projects were successful and highlighted the key benefits of mobile learning for training which are engagement with learning, flexibility of learning, learner retention and achievement, personalization of learning, and access to learning resources.

Cisco learning network also develop mobile learning applications for IT training [12]. These applications are developed specifically for network engineers who want to take the CCNA certification. These applications are only available for selected brands of video-enabled mobile devices; Apple, Android, and BlackBerry.

\section{B. Mobile learning for Teacher Training}

Despite a number of research projects on mobile learning for teacher training, research that focuses exclusively on teachers' development is very limited. Most projects were developed as tools for teaching and learning activities or administrative support.

Some of the mobile learning programs that focus on teacher training in the literature were to solve the problems of training teachers in rural area [13]-[15]. These projects were question-answer based and allowed teachers to access training material, be involved in discussion with other participants and participate in self-assessment. However, the training was not systematic and what competencies the teachers gained after the training is unclear.

Other mobile learning projects were developed to support teachers' mentoring and supervision [11], [16]-[18]. The Projects used mobile devices as a teaching tool which can supplement and/or take the place of face-to-face meetings. Focusing on pre-service teachers, these projects aimed to improve pre-service teachers' practice and employability through self-reflection, peer assessment, peer support, and idea sharing using mobile devices. Pre-service teachers' confidence and ability in using technology were improved by this training.

Mobile learning for teacher training generally utilized 3G mobile phones, Personal Digital Assistants (PDAs), and smart phones, some projects used a particular brand of mobile devices, such as Nokia Communicator 9210 [16], Palm Treo mobile devices [17], Samsung, HTC and iPhone [11], [18] used other mobile devices, such as MP3 and MP4 players, iPod, and Sony Play Stations.

\section{MobILE LEARNING FOR ICT TRAINING}

With the rapid development of mobile technology and the increasing availability of wireless mobile devices in everyday life, mobile learning can be a solution to the problem of delivering ICT training to teachers in Indonesia. The proposed system aims to use mobile phones as a medium to deliver training for teachers in Indonesia.

\section{A. Why Use Mobile Phones?}

Mobile learning as a kind of learning model allowing learners to obtain learning materials anywhere and anytime using all kind of wireless handheld devices such as mobile phones, personal digital assistant (PDA), wireless laptop, personal computer (PC), and tablet [19]. Mobile phones have more potential as a tool for mobile learning than other handheld devices because they are:

\section{1) Available to everyone}

People consider the mobile phone a necessity. In 2011 global penetration of mobile phone subscriptions was approximately $87 \%$ while in Indonesia it was $97.72 \%$ mobile phone subscriptions per 100 inhabitants [20]. A significant factor for the rapid adoption of mobile phones is the price of mobile phones. Mobile phones are cheaper than other handheld devices. Mobile phone prices had decreased by a further $22 \%$ in developing countries in the last decade [20].

\section{2) Low-cost services}

Competition between mobile service providers has caused prices for mobile phone services such as calls, short messages service (SMS), and data transmission to decrease. This has led to the affordable cost of mobile services for everyone.

\section{3) Familiar devices}

People use mobile phones constantly in daily activities. This allows users to really get used to their own mobile phones. Mobile learning participants often prefer to use technologies with which they are already familiar [11].

\section{4) Wide coverage area of the mobile network}

With the wide coverage area of the mobile network, mobile phones can be used in most places.

\section{B. The Proposed Training System}

The architecture of the proposed ICT training system is based on the 1484.1 IEEE Standard for Learning Technology-Learning Technology System Architecture (LTSA). This standard is neutral in terms of pedagogy, 
content, platform and implementation [21]. A main feature of the LTSA is the mapping of the conceptual implementation to the actual implementation.

The proposed mobile learning for ICT training components; training participants, mobile phone, mobile learning application, participants' records and training material, are mapped to the LTSA system components can be seen in Fig. 1. The training participant is represented as the LTSA learner entity. The mobile phone is mapped to the LTSA behavior and multimedia component. The mobile learning application is implemented as an integration of the LTSA evaluation, assessment, coach, locator, delivery, and interaction context component. The learning material and participant record are mapped to the LTSA learning resources and the LTSA learner records respectively.

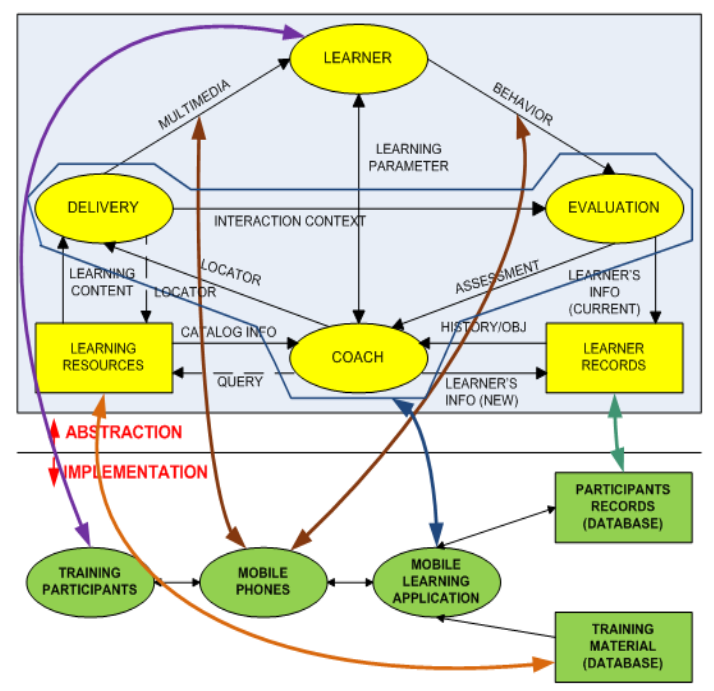

Fig. 1. The proposed mobile learning for training system mapped to the LTSA system components.

\section{Key Features of Proposed System}

The proposed ICT training system will provide the features needed for typical mobile learning for training, such as self-assessment, peer discussion, mentoring and idea sharing. The new features in this proposed system are as follow:

\section{1) Generic application}

Mobile phone application for this ICT training system will be developed to be suited to different platforms of current mobile phone types.

\section{2) Structured and systematic training}

The existing mobile learning programs for teacher training are not systematic as target competency of the training is not defined. With the objective to improve the ICT skill level of teachers, the training will be divided into levels that help teachers to learn ICT step by step. There will be an examination for each level to measure the progress of the teachers.

\section{3) Comprehensive content of ICT training}

Current ICT trainings are not enough for teachers to be able to use ICT in their teaching because the training just focuses on computer literacy with no link to teaching and learning aspects. Another important aspect to be included is
ICT technical support including troubleshooting to prepare teachers for handling computer breakdowns since this problem frustrates teachers when using ICT [1]. The content of this training will cover ICT basic skill, ICT for teaching and learning activities, and ICT technical support.

\section{4) Certification of completion}

Once the highest level of the training course is completed and the examination is passed, the teachers can obtain a certificate of training completion from the training providers. The certificate can encourage teachers to participate as the certificate will support their career development. The teachers will also feel appreciated for their efforts in completing the self-ICT-training.

\section{CONCLUSION AND FUTURE WORK}

Improving ICT skill and knowledge of teachers is essential for the success of ICT integration into education. However various ICT training programs provided for teachers were not really effective in improving teachers' ICT skill due to lack of opportunity, geographical challenges, time, and cost problems. This paper has proposed an ICT training system using mobile phones as a solution for these problems. Mobile phones are widely used, provide low-cost services, and can reach anybody in anyplace. The training system will focus on high school teachers in Indonesia to support them in the implementation of the 2013 curriculum in which ICT is integrated into all subjects in the high school curriculum.

Future work will involve a survey to investigate teachers' current use of mobile phones and to measure their mobile phone self-efficacy as an indicator of their readiness to engage in mobile learning for training. The survey findings will be a basis for developing the proposed ICT training system. A training module will be tested using the system.

\section{REFERENCES}

[1] UNESCO, "Teacher training on ICT use in education in Asia and the Pacific: Overview from selected countries," Information Programmes and Services - UNESCO, 2003.

[2] World Links, The Asia Policy Forum on ICT integration into education: A final report, 2007.

[3] BPSDMPK-PMP Kementerian Pendidikan dan Kebudayaan RI. (12 November 2012). Uji kompetensi guru online. [Online]. Available: http://www.info-ukg.kemdikbud.go.id.

[4] Fajar. (2012). Hasil UKG online banyak nilai nol. [Online]. Available: http://www.fajar.co.id/read-20120803194146-hasil-ukg-online-banya k-nilai-nol.

[5] R. Cobcroft, S. Towers, J. Smith, and A. Bruns, "Mobile learning in review: Opportunities and challenges for learners, teachers, and institutions," presented at the Online Learning and Teaching (OLT) Conference, Brisbane, 2006.

[6] GSMA, "mLearning: A platform for educational opportunities at the base of the pyramid," GSMA Development Fund, 2010.

[7] R. Buckley and J. Caple, The theory and pratice of training, Kogan Page Ltd., 2000.

[8] D. Sampson, "Supporting Vocational Education and Training through mobile learning environments," presented at The 6th International Conference on Advanced Learning Technologies, 2006.

[9] T. G. Tucker and W. W. Winchester III, "Mobile learning for Just-In-Time application," in Proc. The 47th Annual Southeast Regional Conference, pp. 1-5, 2009.

[10] S. Martin et al., "Work in progress: A mobile performance support system for Vocational Education and Training," presented at the The 39th ASEE/IEEE Frontiers in Education Conference, San Antonio, TX, 2009. 
[11] R. Douch, C. Savill-Smith, G. Parker, and J. Attewell. (2010). Work-based and vocational mobile learning: Making IT work. [Online]. Available:

http://moblearn21.blogspot.com.au/2011/07/work-based-and-vocation al-mobile.htm.l

[12] Cisco. (2012). Cisco M-Learning mobile certification study. [Online]. Available:

https://learningnetwork.cisco.com/community/learning_center/m-lear ning .

[13] J. Zhu and Z. Zhou, "Continuing education and training of teachers in rural area based on mobile learning and mobile services," presented at The 1st International Conference on Information Science and Engineering, pp. 3723-3725, 2009.

[14] J. Wu, L. Qi, and Z. Hu, "3G phone-based mobile learning for improving K-12 teachers' educational technology in rural area," presented at The 2nd International Workshop on Education Technology and Computer Science, 2010.

[15] G. Liu and Z. Jiao, "The design of mobile learning system for teachers' further education," in Proc. The 2nd International Workshop on Education Technology and Computer Science, pp. 730-732, 2010.

[16] P. Seppala and H. Alamaki, "Mobile learning and mobility in teacher training," presented at The IEEE International Workshop on Wireless and Mobile Technologies in Education, 2002.

[17] J. Wishart, "Use of mobile technology for teacher training," Mobile learning: Transforming the delivery of educational training, M. Ally, Ed., ed: Athabasca University Press, 2009, pp. 266-278.

[18] A. Crushing, "A case study of mobile learning in teacher training Mentor Me (Mobile Enhanced Mentoring)," Medien Padagogik, pp. $1-14,2011$.

[19] F. Ozdamli and N. Cavus, "Basic elements and characteristics of mobile learning," Procedia - Social and Behavioral Sciences, vol. 28, pp. 937-942, 2011.

[20] International Telecommunication Union (ITU), "The world in 2011: ICT Facts and figures," 2011.

[21] IEEE - Computer Society, "1484.1 IEEE Standard for Learning Technology - Learning Technology System Architecture (LTSA)," ed., Institute of Electrical and Electronics Engineers, Inc., 2003.

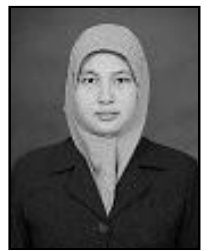

Iin Karmila Yusri is a PhD candidate in School of Computer Science, Engineering and Mathematics, Flinders University, Australia, on leave from Computer and Networking Engineering Department, Politeknik Negeri Ujung Pandang, Indonesia.

Her research interest is the application of mobile network and information technology in education.

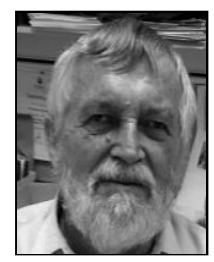

Robert Goodwin is with School of Computer Science, Engineering and Mathematics Flinders University, Australia.

His latest publications are Individual Acceptance of SMS-based E-Government Services: A Conceptual Model. In Patel F. et al., ed. Information Technology Development, and Social Change. New York, Routledge, pp. 72-91 (2012) and Evaluation of Organizational E-Government Readiness in the Public Sector in International Journal of E-Services and Mobile Applications (2013). He is also co-authored two more books used in Australian Schools.

His research interests relate to the application of information technology in business and education. In particular, he is interested in developing models for strategic planning in the application of ICT in developing countries. His current research is in developing models for the application of mobile phones and SMS messaging in e-government and e-commerce in developing countries, culturally sensitive models for e-learning in developing countries and strategies for e-government.

Dr. Robert Goodwin is member Australian Computer Society Settoer/Vettor SACE exams and member of the programming committee and peer reviewer for 5 International conferences. 